\title{
凍結抑制舗装の問題点と評価について
}

\section{Application of Pavement for Prevention of Freezing and Deicing}

稲 坦 竜 興*

Tatsuoki Inagaki

\section{1.はじめに}

スパイクタイヤの使用が規制されて以降の積雪寒 冷地域における冬季の交通安全対策として, 舗装に よる路面の倲結対策が大きくクローズアップされて きている。

最も効果が大きいとされているのは, 舗装路面の 温度を凍結温度以上に保つ路面ヒーティングによる 方法であるが，イニシャル，ランニングとあコスト が高く，広く普及するに至っていない。

次善の対策として，多くの凍結抑制舗装工法が提 案されているが, 何れの工法も何らかの問題点を持っ ていると言える。

ここでは，現在提案されている凍結抑制舗装の問 題点とその評価方法について示す。

\section{2. 路面の凍結対策の現況}

路面の凍結は，車両によって踏み固められた雪が 低温のため路面に凍りついたすのや，一度融解した 雪が温度低下によって再び凍結したもの，降雨など による路面上の水分が温度低下により凍結したあの などがある。

さらに, 最近では積雪寒冷地域におけるスパイク 夕イヤの粉塵公害問題から, 平成 2 年 6 月 27 日に 「スパイクタイヤ粉塵の防止に関する法律」が公布
され, 平成 3 年 4 月 1 日以降指定地域でのスパイク タイヤの使用が禁止されてきた。こういった状况か らスタッドレスタイヤ使用者が増加し，冬期間の路 面状況は従来のアイスバーンとは異質の，いわゆる 「ミラーバーン」(除雪直後の鏡面化した氷結路面) や「つるつる路面」あるいは交通啮滞の激しい街路 や交差点部分では「こぶ水路面」といわれる新たな すべり易い路面が出現してきており，交通事故や交 通淽帯が頿発してきている。

こういったことから路面の滑り止め対策の一圌と しての凍結抑制あるいは融雪舗装に期待が集まって きており，効果的な工法の提案が急務となってき た。以下に一般的な凍結抑制舗装についての概要を 示した。

\section{(1) 凍結対策の概要}

積榋寒冷地における道路の路面凍結防止対策工法 は，現段階で表ー 1 の通りである。

これらの内わが国では，除雪対策として一般的に 機械による除雪が多く用いられている。また，路面 のすべりおよび早期の融雪対策としては砂の散布が 行われており，凍結防止には楽剂の散布が一般的で ある。しかし，これらの工法は一般に維持管理が煩 雑で, また楽剂散布では道路構造物や沿道環境への 塩害が懸念される。 
表 -1 路面凍結防止工法

\begin{tabular}{|c|c|c|c|}
\hline 工法の分類 & 使用目的 & 特 & 課 \\
\hline $\begin{array}{l}\text { 機械による除雪除 } \\
\text { 雪車、グレーダ }\end{array}$ & 除 雪 & 積雪量の多い場合む対応できる。 & 凍結防止効果はない。 \\
\hline $\begin{array}{l}\text { 薬剤散布 } \\
\text { 塩化ナトリウム } \\
\text { 塩化カルシウム } \\
\text { 塩化マグネシウム } \\
\text { 尿素 } \\
\text { CMA }\end{array}$ & 凍結防止 & 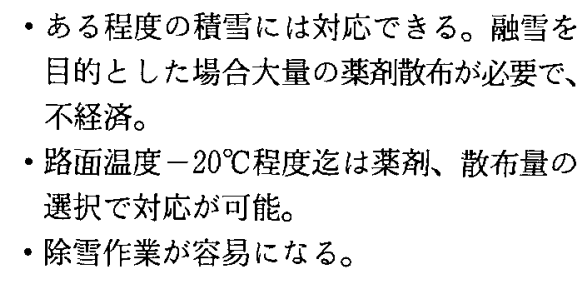 & $\begin{array}{l}\text { 薬剤よして塩化物が用い } \\
\text { られることから、定期的に } \\
\text { 大量に散布される地域では } \\
\text { 塩害の発生があり、問題と } \\
\text { なっている。 }\end{array}$ \\
\hline 細骨材（焼砂） & $\begin{array}{l}\text { 滑り止め } \\
\text { 雪解早期 }\end{array}$ & $\begin{array}{l}\text { 単独または薬剤と併用し効果あり。主に坂 } \\
\text { 道で使用。 }\end{array}$ & $\begin{array}{l}\text { 雪解け時に路肩、排水桝 } \\
\text { の砂回収が必要。 }\end{array}$ \\
\hline $\begin{array}{l}\text { 消雪パイプによる } \\
\text { 散水 }\end{array}$ & $\begin{array}{l}\text { 融 雪 } \\
\text { 凍結防止 }\end{array}$ & $\begin{array}{l}\text { ・気温が極端に低くない所では有効。 } \\
\text { ・温泉水、加温水、塩水の場合は極低温で } \\
\text { も効果あり }\end{array}$ & $\begin{array}{l}\text { 地下水散布の場合は地盤 } \\
\text { 沈下の可能性があり、要注 } \\
\text { 意。 }\end{array}$ \\
\hline ロードヒーティング & $\begin{array}{l}\text { 融 雪 } \\
\text { 凍結防止 }\end{array}$ & $\begin{array}{l}\text { 融雪、凍結防止効果の信頼性は高い。時 } \\
\text { 間当たり降雪量の多い場合は限界あり }\end{array}$ & $\begin{array}{l}\text { 他と比べ経済性に問題が } \\
\text { ある。 }\end{array}$ \\
\hline 蓄熱舗装 & $\begin{array}{l}\text { 融 雪 } \\
\text { 凍結防止 }\end{array}$ & $\begin{array}{l}\text { ・ロードヒーティング と同等の効果が期 } \\
\text { 待できる。 } \\
\text { ・熱源が太陽熱または地熱であるためラン } \\
\text { ニングコストが低い }\end{array}$ & $\begin{array}{l}\text { 熱源が太陽光および地熱で } \\
\text { あることから熱の持絸性が } \\
\text { ある。 }\end{array}$ \\
\hline 凍結抑制舗装 & 凍結防止 & $\begin{array}{l}\text { ・維持管理が容易である。 } \\
\text { ・極低温では効果が少ない }\end{array}$ & $\begin{array}{c}\text { 凍結抑制効果の持続性、 } \\
\text { 舗装の耐久性に問題がある。 }\end{array}$ \\
\hline
\end{tabular}

ロードヒーティング, 散水による消雪, 蓄熱舗装 は日常の維持管理が容易であるが，経済性や地盤沈 下の問題から適用䇢所の選定に配慮が必要となる。

凍結抑制舗装は, 路面上での初期凍結の防止と雪 水の付着防止を目的亡するすのである。この工法は 舗装自体では雪や水を溶かすことはないことから， 他の工法と比べて除雪効果や極低温での路面凍結防 止性能は低くなる傾向があるが，適用地域の気象条 件等を把握して使用すれば，維持管理の容易性から 非常に有効なものである。

\section{(2) 凍結抑制舗装の種類と分類}

凍結抑制舗装は, その材料特性加ら大きく次の 3 つに分類できる。

(1) 塩化物系……塩化カルシウム，塩化ナトリウム 等の塩化物および特殊な石粉, 骨材, 油等を混合
固化したものを骨材と同様にアスファルト混合物 に添加し混合したものや，排水性舗装などの空隙 率の大きな埔装の中に塩化物を散布充填したもの。

(2) 不凍液系……排水性舗装等の高い空隙を有する 舗装の空隙の中に不凍液を浸透させたもので，浸 透した不凍液が流出しない上うに特殊な添加珴で ゲル化させたもの。

(3) 弾性 系……アスファルト混合物内に粒状ゴム を添加したすの，あるいは舗装表面に孔を開け， 円柱形に整形したゴムを差し込んだすの，路面に グルービングを行い, 溝にウレタン樹脂を注入し たもの，ゴムパイプを舗装に埋め込んだあの，さ らに廃タイヤや人工のゴム板をコンクリート版に 張りつけて敷ならしたもの。 などがある。これらを表ー 2 に示す。 
表 -2 凍結抑制舗装の種類と概要

\begin{tabular}{|c|c|c|c|c|c|}
\hline $\begin{array}{l}\text { 添加材 } \\
\text { 区 分 }\end{array}$ & 商品名 & 主成分形状 & 原理および特徵 & $\begin{array}{l}\text { 凍結 } \\
\text { 温度 }\end{array}$ & 備 \\
\hline \multirow{2}{*}{ 塩 } & $\begin{array}{l}\text { ベルグ } \\
\text { リミット }\end{array}$ & $\begin{array}{l}\text { 塩化カルシゥム } \\
\text { 粒径 } 0.1 〜 5 \mathrm{~mm} \text { の } \\
\text { 顆粒状骨材 }\end{array}$ & \multirow{4}{*}{ 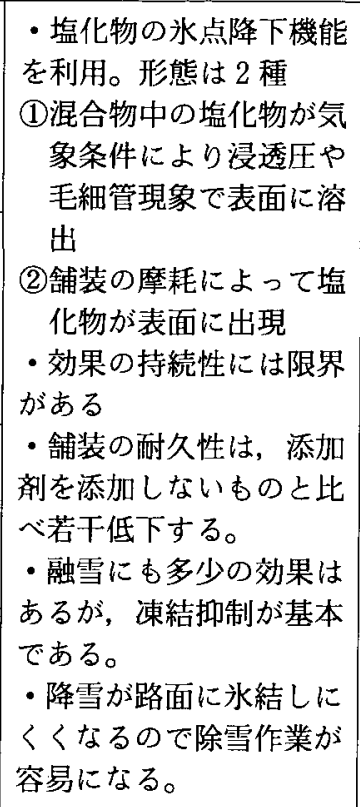 } & \multirow{4}{*}{$\begin{array}{l}-3{ }^{\circ} \mathrm{C} \\
\text { 程度ま } \\
\text { で }\end{array}$} & $\begin{array}{l}\text { 塩化カルシウムの表面を } \\
\text { 亜麻仁油でコーティング } \\
\text { することによって塩化物 } \\
\text { の溶出をコントロール }\end{array}$ \\
\hline & マフィロン & $\begin{array}{l}\text { 塩化ナトリウム } \\
\text { 塩化カルシウム } \\
\text { 微粉末 }\end{array}$ & & & $\begin{array}{l}\text { 塭化ナトリゥム、塩化力 } \\
\text { ルシゥム等の無機塩に粘 } \\
\text { 土、石粉を混ぜたもの。 }\end{array}$ \\
\hline \multirow[t]{2}{*}{$\begin{array}{l}\text { 物 } \\
\text { 系 }\end{array}$} & ノンフリーズ & $\begin{array}{l}\text { 10mm以下の骨材 } \\
\text { 状 }\end{array}$ & & & $\begin{array}{l}\text { 特殊塩化物を特殊セメン } \\
\text { トに混入固化後破砕した } \\
\text { もの } \\
\text { 骨材として使用。 }\end{array}$ \\
\hline & 岩塩 & $\begin{array}{l}\text { 岩塩 (堨化ナト } \\
\text { リウム) }\end{array}$ & & & コストが安い。 \\
\hline \multirow{4}{*}{$\begin{array}{l}\text { 弾 } \\
\text { 性 }\end{array}$} & ルビット & $\begin{array}{l}\text { 廃タイヤを急冷 } \\
\text { 粉砕したもの } \\
\text { で, 粒状 }\end{array}$ & $\begin{array}{l}\text { ・添加するゴム粒子にた } \\
\text { わみ性を利用して舗装に } \\
\text { 弾力性を付与。車両荷重 } \\
\text { により舗装がたわみ, 路 } \\
\text { 面の水結層を破壊する。 }\end{array}$ & \multirow{4}{*}{ 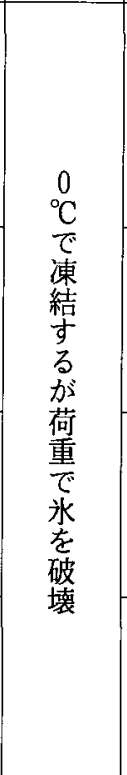 } & $\begin{array}{l}\text { ゴムの弾力性と車両荷重 } \\
\text { による物理的な凍結抑制 } \\
\text { 作用で、水結層が厚い場 } \\
\text { 合や車両荷重が軽い場合 } \\
\text { は効果少 }\end{array}$ \\
\hline & $\begin{array}{l}\text { グルービング } \\
\text { +ウレタン }\end{array}$ & $\begin{array}{l}\text { ウレタン系樹脂 } \\
\text { 幅 } 6 \mathrm{~mm} \text { の溝 } \\
\text { 液状で注入 }\end{array}$ & $\begin{array}{l}\text { 路面に溝を切り，その中 } \\
\text { に弾力性材料を注入車両 } \\
\text { 荷重により路面の水結層 } \\
\text { を破壊する。 }\end{array}$ & & $\begin{array}{l}\text { 原理はルビットと同じで } \\
\text { あるが、耐久性は今後の } \\
\text { 検討が必要である。 }\end{array}$ \\
\hline & $\begin{array}{l}\text { マジック } \\
\text { サークル }\end{array}$ & $\begin{array}{l}\text { 柱状ゴム } \\
\text { 直径 } 5 \mathrm{~cm}\end{array}$ & $\begin{array}{l}\text { 舗装表面に孔を開け, こ } \\
\text { こに柱状ゴムを敷設する。 } \\
\text { 原理はルビットと同じ。 }\end{array}$ & & $\begin{array}{l}\text { ゴム材質はスタッドレス } \\
\text { タイヤや目地材のあのが } \\
\text { ある。費用が高くつく雚 } \\
\text { 点有り }\end{array}$ \\
\hline & $\begin{array}{l}\text { ゴムパイプ/ } \\
\text { 廃タイヤ } \\
\text { ゴムマット等 }\end{array}$ & $\begin{array}{l}\text { ゴムパイプ/廃 } \\
\text { タイヤ等 }\end{array}$ & $\begin{array}{l}\text { ゴムパイプは舗装にゴム } \\
\text { パイプを埋め込むもの。 } \\
\text { ゴムマットは平板に廃タ } \\
\text { イヤを張付け路面に敷く。 }\end{array}$ & & $\begin{array}{l}\text { 耐久性や, 夏期の走行性 } \\
\text { に検討が必要である。 }\end{array}$ \\
\hline $\begin{array}{l}\text { 不 } \\
\text { 速 } \\
\text { 液 } \\
\text { 系 }\end{array}$ & ベック工法 & $\begin{array}{l}\text { 開粒度舗装 } \\
\text { プロピレングリ } \\
\text { コールゲル化則 } \\
\text { 液状で注入 }\end{array}$ & $\begin{array}{l}\text { 排水性舗装等の開粒度舗 } \\
\text { 装の空隙に不凍液を浸透, } \\
\text { ゲル化した不凍液の作用 } \\
\text { で水結防止 }\end{array}$ & $-10^{\circ} \mathrm{C}$ & $\begin{array}{l}\text { ゲル化剂の種類により高 } \\
\text { 温タイプと常温タイプが } \\
\text { ある }\end{array}$ \\
\hline
\end{tabular}




\section{3。凍結抑制舗装の評価について}

表一 2 に示すように，凍結抑制舗装は各種の工法 が提案されてきており，さらに新たな開発が行われ ている。一方で，その評価方法が定まっておらず， 工法採用に当たってどの程度の効果を期待すべきか が判定しにくい状況にある。従って，凍結抑制舗装 の実用化のために，その機能を定量的に評価する方 法がのぞまれている。

見在,一般的な物理的謶価方法としては, 建研式 引き拔き試験器による路面との水着程度を計るあの, 北海道開発局提案のせん断による水着力測定方法お よび北海学園大学武市先生提案の土質用一面せ九断 試験器の応用方法などがある。

これらのうち，上部から荷重をかけ，せ九断試験 を行う一面せん断試験方法が，最屯現害の路面およ び挙動に近いもの之考え, 荷重, 荷重速度および変 移等を自動化した改良試験器によって, 評価試験を 行った。以下にその概要を示す。

\section{(1) 実験概要}

本実験に用いた凍結抑制舗装用の混合物は，細粒 度ギャップアスファルト湿合物 (13F) に塩化物系 添加剂を $5 \%$ 添加したもの(A)，特殊ギャップ型粒 度のアスファルト混合物に廃夕イヤを急冷粉研した ゴム粒子を $3 \%$ 混入したもの（B）および目標空隙 率を18\%の排水性舗装用アスファルト混合物 (13) の空隙に不凍液などからなる凍結防止材を充填した あの(C) の 3 種類とした。

実験方法は, 図ー 1 に示す一面せん断試験器を用 い，凍結抑制舖装と着水層の境界面がせん断面に一

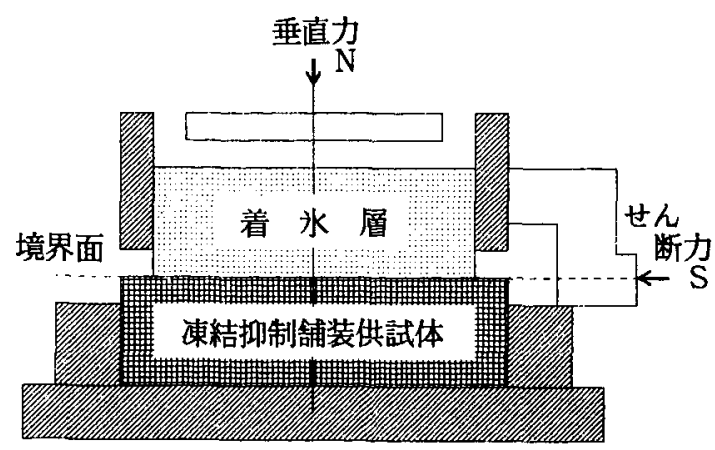

図一１－面せん断試験の方法
致するようにして，垂直方向に荷重（N）をかけた 状態で水平方向にせん断力 $(\mathrm{S})$ を加え，水を押し はがす時の最大せん断力を着水面積で除して得られ るせん断応力を求めるあのである。せん断応力が小 さいほよ゙着水しづらいことを表している。なお，垂 直方向に一定の荷重を加えることは，車両重量の影 響を考慮しているあのである。

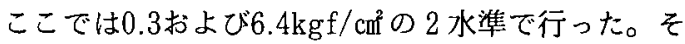
の他試験条件は表－3に示す。

\section{表一 3 試験条件}

\begin{tabular}{|c|c|}
\hline 項 & 件 \\
\hline 供試体寸法 & $\phi 10 \mathrm{~cm} \times 5 \mathrm{~cm}$ \\
\hline 着水層寸法 & $\phi 6 \mathrm{~cm} \times 3 \& 25 \mathrm{~mm}$ \\
\hline 垂直応力 & $0.3,6.4 \mathrm{kgf} / \mathrm{cm}^{2}$ \\
\hline 変 位 速 度 & $1 / 100 \mathrm{~mm} / \mathrm{min}$ \\
\hline 試 験 温 度 & $-2, \quad-5, \quad-10^{\circ} \mathrm{C}$ \\
\hline
\end{tabular}

なお，供試体は供用後 2 ヶ程度の車両走行を受 けた路面を想定し，簡易回転ラベリング試験を実施 したホイールトラッキング試験用の $30 \times 30 \times 5 \mathrm{~cm}$ の 形状のあのからコアーカッ夕に上り切り出した。

簡易回転ラベリング試験は，供試体面が $0{ }^{\circ} \mathrm{C}$ の湿 㵎状態としタイヤ走行を実施した。タイヤは二ュー マチックの表面にスタッドレスタイヤの表面部を張 りつけたすので接地圧 $3.7 \mathrm{kgf} / \mathrm{cm}^{2}$, 供試体の回転数 60 r.p.m，通過輪数 11,720 回とした。

\section{(2) 実験結果と考察}

着水層の厚さ $3 \mathrm{~mm}$ の時の一面せん断試験結果を図 - 2 に, $25 \mathrm{~mm}$ の時の結果を図一 3 に示す。 試験結果から以下のことが明らかになった。

(1) せん断応力は着水層の厚さが薄いほど小さくな る傾向がある。

(2) せん断応力は試験温度が $0{ }^{\circ} \mathrm{C} に$ 近づくほじ小さ くなる傾向を示した。

(3) せん断応力は垂直応力が小さいほど小さくなる 傾向を示した。なお，弾性力を付加したBのせん 断応力が, 垂直応力が大きくなるほど小さくなら なかったのは拘束した着氷層に加えた重直荷重の 加え方に工夫が必要であると思われる。

(4) せ九断応力は B とCでそれはど顕著な差が見ら 


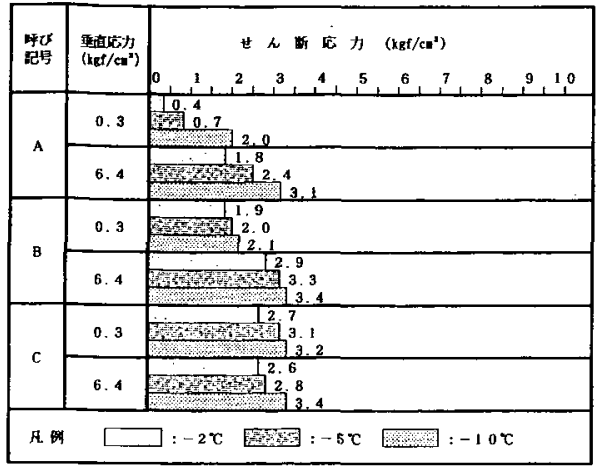

図－２一面せん断試験結果（着水層の厚さ：3mm）

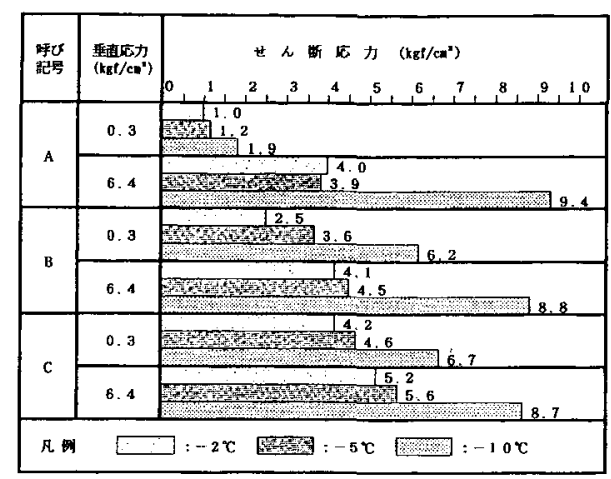

図－３－面せん断試験結果（着水層の厚さ：25mm）
れなかったが， A， B，Cの順で小さい傾向を示 した。

\section{4.あとがき}

今回の测定值は供用後初期の状態を想定して求め た結果であり，それぞれの供試体の供用状態によっ てこれらの傾向も変化することが考えられる。した がって, 凍結抑制舗装の耐久性を評価する上で, 経 年変化の合わせた供試体の作成方法など, 今後の課 題であるといえる。

今後，効果的な凍結抑制舗装を開発する上で，ま たは凍結抑制舗装の機能を管理する上で，ここに示 した様な定量的な試験評価方法が必要となることか ら, さらに試験条件や試験方法の改良を含めて提案 していくことが必要である。そういった意味で本報 分が参考になれば幸いである。 